\title{
Latin America Marine Corps: between the past and the future ${ }^{1}$
}

\author{
Marcos Pablo Moloeznik ${ }^{2}$
}

"When the Soldiers of the world are gone, when the absolute peace reigns, only the Marines should remain as example of everything beautiful and fascinating they were"

Rachel de Queiroz, Brasilian writter (1910-2003)

\begin{abstract}
Within the framework of the VII Marine Leaders of the Americas Conference (MLAC) held this year in Mexico City from March 12 to 16, it is appropriate to stop along the way and review the genesis, development, historical evolution and future perspectives of the terrestrial component of naval power in Latin America. The origins date back to the Spanish colonial era, in the case of the Spanish-speaking countries, and the Portuguese era, in the case of Brazil.

With this purpose in mind, brief considerations on the nature of the Marine Corps are presented, the past of the selected navy amphibious bodies of Latin America is explored, as well as their current situation and their future projection in the face of traditional and emerging threats, including a reflection on the three paradigms of naval power in the region in accordance with classic British naval doctrine.
\end{abstract}

Key words: Marine Corps, Naval Power, Latin America, Past, Future

Resumen: En el marco de la VII Conferencia de Líderes de Infantería de Marina de las Américas (CLIMA) celebrada en Ciudad de México en la semana del 12 al 16 de marzo del corriente año, resulta apropiado hacer un salto en el camino y llevar a cabo un análisis comparado del componente terrestre del poder naval de América Latina, los cuerpos de infantería de marina, mediante una revisión de su devenir histórico, a partir de la era colonial de España para el caso de los países hispano-parlantes y de Portugal, tratándose de Brasil.

Con este propósito, se parte por considerar la naturaleza de los Cuerpos de Infantería de Marina, su pasado mediante una selección de los mismos, para dar cuenta de su situación actual y perspectivas a futuro de cara a las amenazas emergentes, incluyendo una reflexión sobre los tres paradigmas del poder naval en la región en concordancia con la doctrina naval británica clásica.

Palabras clave: Infantería de Marina, Poder Naval, América Latina, Pasado, Futuro

\footnotetext{
${ }^{1}$ Recibido: 15/06/2018. Aceptado: 16/10/2018

${ }^{2}$ Profesor e investigador de la Universidad de Guadalajara, México. E mail: mmoloeznik@yahoo.es
} 


\section{Forewords}

Unlike the Army, which is the main armed force in Latin America, the Navy is practically unknown because there is limited research on the latter. In addition, there is a new instrument of "parallel diplomacy", the Marine Leaders of the Americas Conference (MLAC), which differs from the traditional Inter-American Naval Conference (INC), celebrated every 2 years since 1959. The MLAC, as a cooperation mechanism for the hemispheric Marine Corps, provides this component of the navies autonomy. The only exception is the United States' Marine Corps, which is an armed force in itself. Therefore, this paper will assess the nature, historical evolution, current situations and perspectives in relation to the emerging threats posed to the main Latin American Marine Corps: Argentina, Brazil, Chile and México

It is necessary to mention first that the Marine Corp is one of the four dimensions of the Navy, and its missions, doctrine, capabilities, operational strategies and tactical dimension respond to national objectives and interests, and to the naval power of each particular case (Moloeznik, 2011). Liddell Hart (1960: 17) identifies this institution as "a self-contained and sea-based amphibious force [...] the best kind of fire extinguisher because of its flexibility, reliability, logistic simplicity, and relative economy".

Conversely, Luttwak and Koehl (1991: 379) define it as primarily trained, organized and equipped for amphibious war, this implies the disembarkment of troops on hostile coasts. According to Sohr:

Traditionally they were the main source of the colonial powers, who dispatched them to quell the native rebellions. The only way to reach the remote colonies on time was through the use of ships. [...] Marine Corps eventually gained autonomy and carried out more complex missions, becoming an amphibious force dependent on the navy, only for its transport. (1990: 123)

This was also recognized by Slater (1998):

[...] Navy forces provide the fastest means of deploying a logistically self-sustaining and tactically congruent force over great distances, providing an invaluable ability for a timely presence and thus, the ability to contain problems at their origin. If this fails, they have the resources of demonstration, coercion or combat; which can shape the operating environment together with anticipation of heavier forces and play a role in supporting them once they arrive in the operation theater.

In other words, Marine Corps constitute the coercive instrument of a nation-state, as the monopolist's detonator over war, whose function is to serve as an amphibious force of the Navy, allowing naval power to project beyond the aquatic area, acting both on land and in air space.

An official Spanish source emphasizes the added value of having a marine corps, namely:

[...] Ideal force for a preventive deployment of initial crisis or as an initial, rapid and forceful response in the event of an open conflict. Besides, the support provided by the Naval Force allows the Marine Corps to remain on land in a conflict zone or to carry out peace operations for a long time and with a minimum logistic footprint. In conclusion, it is its own amphibious nature that endows the Marine Corps with an incomparable expeditionary character [...] (Spanish Marine Corps, 2018: 10 and 11) 
In general, there is a consensus on its nature, as a high-level enlistment force, considered to be elite and characterized by its versatility, skills and flexibility, which allows to perform counterinsurgency tasks, to provide humanitarian aid, to support peace operations, to perform evacuation operations of non-combatants and to carry out evacuations under military protection.

But what is a Marine? According to the United States Marine Corps (USMC):

Being a Marine is a state of mind. It is an experience some have likened more to a calling than a profession. Being a Marines is not a job -not a pay check; it is not an occupational specialty [...] it is a searing mark in our innermost being which comes after the rite of passage through boot camp or Officer Candidates School [...] Marines believe that to be a Marine is special; that those good enough to become Marines are special; and that the institution in which they are bonded is special [...] $(1995: 7,23)$

In other words, a Marine is different from other combatants due to his/her unique characteristics, such as esprit de corps, leadership, traditions, readiness, the ethos representing that "every Marine a rifleman", adaptability, innovation, decentralization, will and victory desire. (Ibidem, 7-52)

\section{Genesis of the marines corps}

The Marines find their origins in the first half of the sixteenth century, when the powers that be decided to equip the ships with trained and skilled troops in order to preserve the safety and defense ability of naval vessels themselves, as well as the approach to the prey; they required different personnel than the usual seamen. These were men who had experience in ground combat and who could be channeled to the theater of naval operations.

The first Marine Corps was founded in Spain and it is in fact the oldest of the world. It was created by the King Charles I on February 27, 1537, by permanently assigning the squads to the Old Companies of the Sea of Naples' galleys. The old arquebusiers, who totaled 30 galleys, were grouped in a special body and were trained to fight "by land and sea". (Royal Spanish Navy, 2012a). Later, in 1566 with Philip II of Spain, they constituted a true force of amphibious landing projection (ABC Journal, 2012). At that time, the Marine Corps belonged to the famous "Tercios" (Spanish Marine Corps, 2018):

1. Tercio of the Sea of Naples.

2. Tercio of Navy of the Ocean Sea.

3. Tercio of Galeras of Sicily.

4. Old Tercio of the Ocean Sea and of the Neapolitan Infantry.

The first of these is the "alma mater" of the Spanish Marine Corps.

The official history of the Marine Corps concludes with its attributes since its genesis, namely:

[...] The aim was to ensure that the Spanish Infantry Tercios' efficiency could be transferred to the sea, so that the new combatant would fight as effectively both on board ships and on land once it had landed. It is the amphibious capacity, the symbiosis between combat techniques on land and the marine environment, the final twinning between the infantryman and the sea. (Royal Spanish Navy, 2012b)

Subsequently, in 1618, the first regiment of Portuguese Marine Corps was created (Terço da Armada Real da Coroa de Portugal), the second in chronological order. Corpo 
de Fuzileiros, conceived as a force of special operations aimed at carrying out amphibious operations, performing coastal reconnaissance, boarding in the high sea, as well as ensuring naval vessels and naval installations safety. The antecedent of the Tercio of the Royal Navy dates back to 1585, when there were specialized troops in charge of the artillery and riflemen on Portuguese warships. It should be noted that the Tercio of the Royal Navy is eventually considered an elite unit, even becoming responsible for preserving the physical integrity of the Portuguese King (Brazilian Navy, 2018b).

The Corpo de Fuzileiros / Marine Corps constitutes a light infantry of the Portuguese Navy (Marinha de Guerra Portuguesa) with the capacity to execute several and diverse missions, whose origin admittedly dates back to the corps of oldest Marine Corps in the world, that is to say, the Spanish "Tercio de la Armada" (Portuguese Marine Corps, 2017).

The creation of today's British Royal Marines (2014) dates back to the reign of King Charles II, recognizing his date of birth on October 28, 1664 as the Duke of York and the Maritime Regiment of Albany (or Admiral Regiment ); the word "Marines", though, is recorded to have been used for the first time in 1672 and "Royal Marines" in 1802 by King George III (also see, Foster, 1998).

The United States Marine Corps (USMC), conversely, finds its origin on November 10, 1775, in Philadelphia as naval infantry, when Captain Samuel Nicholas forms two battalions of continental marines by Congressional order (Hoffman, 2002:11). Since then, however, the mission of the USMC has undergone significant evolution following the dynamics of both US military doctrine and foreign policy.

It should be noted that the USMC is present in all armed conflicts of the American Union and reaches its fame in the twentieth century, "when its theories and practices of amphibious war were premonitory and finally formed the cornerstone of the Pacific campaign of The Second World War" (Corps, USM, 2014: 2).

\section{Marines Corps in Latin America: between the past...}

Latin American armies are characterized by their rich traditional component of the projection of the naval power on land, a legacy left by both Spain and Portugal (Scheina, 1987: 217-223). Thus the Marine Corps of the New World were born from the troops of the Tercio sent to the American continent. For example, Jorge Ortiz Sotelo (2000: 19, 23 et seq.) shows that a colonial military organization existed in Peru which fulfilled that role for more than two centuries.

The official history of the Argentine Navy states that the origins of the Marine Corps of the Argentine Navy are linked to the troops of the Tercio of the Spanish Ocean Sea sent for landing operations, with the objective of securing the borders of the then Viceroyalty of the Río de la Plata.

Even the origin of Chilean Marine Corps dates back to the 16th century. Since colonial times, Chile has been exposed to filibusters' incursions, a threat that paved the way for the organization of coastal defense units in order to cope with it.

the Corpo de Fuzileiros Navais from Brazil, however, is considered to be the oldest in Latin America, having its origin in the Portuguese Royal Brigade, which arrived in Brazil with the Royal Family in 1808. Upon returning the court to Lisbon, a Battalion remained in Brazil, as the hard nucleus and embryo of its heir, the terrestrial component of naval 
projection of the giant of South America (Scheina, 1987: 219 and 221). This is confirmed by an official Brazilian source:

The date of 1808 was chosen as the origin of the Brazilian Marine Corps. In this year, the Portuguese royal family leaves the court in Lisbon and transfers it to Rio de Janeiro. This was a measure to prevent the Portuguese Crown from losing its main colony. Napoleon pressured the Portuguese royal family to break relations with Britain and declare war on this nation, putting Lusitanian leaders at a crossroads, declaring war on London would mean losing control over Brazil, and not doing so would mean to be invaded by France. The exit to Brazil was the solution to maintain control over that territory and at the same time, not to submit to Napoleon. (Brazilian Navy, 2018b)

Another source further confirmed that:

[...] Royal Navy Brigade components garnished the Portuguese war vessels that transported the Portuguese Royal Family, their Court, and their State apparatus to Brazil. After a long voyage the Marines of the Portuguese Royal Brigade landed in Rio de Janeiro on 7th March, 1808, the date that marks the Anniversary of today's Brazilian Marine Corps. (Medeiros, 2013: 10)

Additionally, during the Spanish-American wars for independence, the national emerging armies included marines, a legacy from the Mother Country.

In this context, José de San Martín, during his campaign to liberate Peru from Spain, favoured the amphibious and even ex ante war -on March 15, 1814. Guillermo Brown occupied Martín García Island - a strategic position in the rivers of La Plata and Uruguay - by means of an operation to disembark troops (Cabanellas, 1984: v. IV, p. 105).

As a result of the Battle of Chacabuco - fought on February 12, 1817 - in which the Army of the Andes defeated the royalist army, the patriot forces gained control of Santiago and Valparaiso, while supporters of the King remained in possession of Concepción, Talcahuano, Valdivia and Chiloé. After this decisive victory, Bernardo O'Higgins Riquelme pronounced the famous phrase that left no doubt about his maritime vision: "This triumph and a hundred more will become insignificant if we do not dominate the sea" (Chilean Navy, 2018a), a vision that he shaped by establishing as the central task of his government the formation of a naval force capable of disputing Spain's domination of the sea and dislodging the realists of southern Chile and El Callao (Peru), which was the only way to consolidate the independence of the Spanish-American peoples. According to the Chilean Navy (2018b):

General Bernardo O'Higgins clearly conceived the aspects of Maritime interests of Chile, undertaking actions to consolidate a Navy, Merchant Marine, fishing ports and an "oceanic-political" conception that guided him in his thinking during his 64 years of life, until - when in his deathbed - with a shrewd voice he repeated the expression "Magellan" - "Magellan".

The campaign of "corso" by Hipólito Bouchard and the Frigate "Argentina" (18171818) should also be mentioned. He took over the city of Monterrey (the capital, in those times, of the Spanish California) by landing with troops of marines led by Lieutenant Jose Maria Piris, which allowed the raising of the Argentine flag in that realistic bastion between 24 and 29 November, 1818.

In the same year, an infantry company and an artillery brigade were formed in Chile, both belonging to the Navy. During the wars of independence, the Chilean marines 
acquired more amphibious experience than any other body in the Western Hemisphere, performing garrison services at the end of the struggle (Scheina, 1987: 221-222).

In contrast with its fellow countries in the region, during its independence Mexico failed to inherit the capabilities or naval means of its former metropolis, as a reault of which its Navy is formed in an improvised manner upon the need to face the Spanish garrison of San Juan de Ulúa, Veracruz. As highlighted by Rodríguez Ávila (2012: 132), "this situation also demanded the presence of a body that would protect the coast of the Gulf of Mexico and prevent smuggling in the area, for that was created the Marine Battalion of Veracruz in 1822", a historical landmark that is considered the moment of the Mexican marine's corps foundation.

In the case of the Brazilian Marine Corps, during the first half of the Nineteenth Century they actively participated in the expansionist and consolidation missions carried out through the Brazilian territory. Since their independence, declared on September 7 1822, the Navy acted to repress the demonstrations against the new regime and has sought to ensure the integrity of the national territory (Brazilian Navy, 2018a).

In general, the official birth of the bodies of Latin American Marine Corps can be rigorously said to have been located in the second half of Nintheenth Century. For example, the Chilean Marine Corps were born in 1860, due to the technological advances of both naval and coastal artillery, which needed a specialized body to handle it. A specific school for the training of marine officers and non-commissioned officers was created to this end: "Thus, on October 1st 1869, overcoming many problems arising from the small space of the Valparaiso Barracks, the first Escuela Central del Cuerpo de Artillería de Marina was founded, to which, later, Academies were added" (Chilean Navy, 2018a).

At that time, Brazilian geopolitics focused on the Rio de la Plata region out of concern in connection with its neighbors Argentina, Paraguay and Uruguay. The Brazilian empire took the strategic initiative and intervened in Argentina in 1851, in Uruguay in 1852 and Paraguay in 1864-65. In 1864, thus, the most important international armed conflict in the history of Brazil began: the Triple Alliance War or Paraguay War, between Paraguay and the alliance of Argentina, Brazil and Uruguay, with severe consequences for all the belligerents.

During this conflagration, the Brazilian navy enabled the landing of the allied armies of Argentina, Brazil and Uruguay in Paso de la Patria; a combined operation considered one of the river crossings of greatest significant and greatest execution in the military history of Latin America.

The need for investment and reformulation of the Brazilian Armed Forces to confront this armed conflict had an effect on the future coup d'état that put an end to the Brazilian empire and established the Republic. In addition to being present in international conflicts, the naval force was also committed to the maintenance of internal order, as can be seen in the repression against the strike carried out by the workers of the port of Santos in 1864 (Bielinski, 62). Later, in 1893, a revolution broke out in the Brazilian navy against the Republican government in power during 1889. The aim of those who rose up in arms was to call elections in compliance with the letter and spirit of the Constitution of the Republic. The revolution was repressed, though, and the naval body dissolved, only to resurface in 1895 as the Marine Corps (Ibidem, 71 et seq.)

In the case of Argentina, the qualitative leap of the Navy and its Marine Corps could be seen with president Domingo Faustino Sarmiento, who made the decision to create a 
squadron (1872) and an arsenal to store supplies or repair the warships (Arsenal Naval Zárate, 1873), to fortify Martín García Island with the best artillery for the defense of coasts at the time and, especially, to set up the Naval Military School, a naval officer training establishment, which started its activities in 1872.

Two years later, his successor Nicolás Avellaneda contnued Sarmiento's naval work. Thus, on November 26 1874, Avellaneda issued a presidential decree for the creation of a Marine Corps Battalion because it was considered of particular importance for the National Squad service. On the last days of his presidency, on November 19 1879, Avellaneda signed a decree creating an Artillery Corps of the Navy attached to the General Command of the Navy. This decree is particularly imporant in that it determined the official and formal creation of the Marine Corps of the Argentine Navy (MCAN); therefore, its date of issue, November 19, is considered as the starting point of its organic life (Argentinean Navy, 2018).

Throughout Latin America's recent history, the Marine Corps have been destined for multiple missions and functions, both in relation to outward boundaries and in order to address domestic problems and threats. This can be sufficiently illustrated by the performance of MCAN during the armed conflict of the South Atlantic Sea (April-June 1982) between Argentina and the United Kingdom of Great Britain. The MCAN is covered in glory by carrying out two key actions, namely:

1) The recovery of the Malvinas Islands, by means of a traditional landing maneuver called Operation Rosario led by Operative Force 40 under the command of Rear Admiral IM VGM Carlos Büsser, to which the landings in the archipelagos of Georgias and Sandwichs del Sur were added (Blakeway, 1992: 38); and

2) The defense of Puerto Argentino, for which Infantry Battalion No. 5 (BIM 5) stood out as "professional soldiers of a very high standard" (Ibidem, 157), under the orders of IM VGM Frigate Captain Carlos Hugo Robacio (1996).

For this, the Argentine Navy (ARA) was forced to commit to the fullest, with almost all its capabilities, resources and means: (Informador Público, 2015)

In "Operation Rosario" three different groups were formed, the first included the transport units; ship for landing cars Q-42 ARA Cabo San Antonio, icebreaker Antarctic Q5 ARA Admiral Irizar and transport Island of the States. Next to these ships were the destroyers D-1 ARA Hercules and D-2 ARA Santísima Trinidad, corvettes P-1 ARA Drummond and P-3 ARA Granville and submarine S-12 ARA Santa Fe. Covering these units of intervention were the aircraft carrier ARA 25 de Mayo, destroyers D-27 ARA Comodoro Py, D-26 ARA Bouchard and D-29 ARA Piedra Buena and tanker B-18 ARA Punta Médanos. The tactical "operation" involved a total of 700 Marines and 100 members of Special Forces.

The well-known historian Scheina of the Naval Academy of Annapolis recounts the efforts of the ARA task force:

After sunset on April 1st, 80 commandos of the amphibious landing troop of marines and naval tactical divers rowed five hundred meters in twenty rubber boats to disembark at 11:00 p.m. Most of the detachment intervened in the making of the Royal Marines barracks, a smaller force took over the government house [...]

The landing craft for cars (Argentinean), Cabo San Antonio, a modified design of the North American "De Soto Country" class, was the first major amphibious ship built in 
Ibero-America. It entered service on February 11th 1978 and in April 1982 it landed the 2nd battalion of Argentine Marines in the Malvinas Islands.

At 6:20 hours, Cabo San Antonio approached and landed nineteen caterpillar vehicles at Yorke Beach [...] 2nd Marine Infantry Battalion [...] A Sea King helicopter, flying from the icebreaker Almirante Irízar, led the 1st Battalion Reserve Marines [...]

At 0015 hours the governor surrendered. The Marines force departed on day 3 by airplanes from the navy and aerial force, leaving to protect the port facilities to a 1st Battalion company. The amphibious vehicles and the support team left the 4th of April in Cabo San Antonio. The army took over the land defenses and later called for a reinforcement of an infantry battalion [...](1987: 270-273)

On April 8th, BIM 5, whose destination was Mount Tumbledown, as part of the defense belt of Malvinas capital, arrived in Puerto Argentino. (Hastings and Jenkins, 1984: 324)

Britain's usual formula of responding with $66-\mathrm{mm}$ and $84-\mathrm{mm}$ rocket fire had no major effect. The Scots Guards could hear the Argentinians shout and even sing as they fought. They were the best troops General Menendez could put on the ground, the 5th Marine Corps [...] As the night progressed and the intense fight continued, they showed no signs of giving in, and their positions held steady.

General Julian Thompson (1982: 248) in charge of the 3rd British Royal Marines Commander Brigade in the Southern Atlantic War joined those voices and called the capture of Mount Tumbledown a "tremendous battle".

The Rattenbach Report on the performance of the Argentine Armed Forces during the Southern Atlantic conflict is more than lapidary and critical, with the exception of some of its own components, such as the case of the Marine Corps on which the following was stated:

BIM 5 [...] demonstrated a joint vocation, a high degree of enlistment, professionalism and adequate equipment, which became evident during land combat, during the defense of Puerto Argentino, action where it had an outstanding performance. (Informe Rattenbach, 1988: 203)

All in all, either during the development of a classic landing operation or in the static defense of positions, the Argentine Marine Corps demonstrated their weight and value.

In the case of Peru, Jorge Ortiz Sotelo (2000: 29 and 75) reports on the responsibilities and actions of the Marine Corps of Peru in the war against terrorism. According to this historian, in May 1980 the Sendero Luminoso terrorist group declared war on the Peruvian State. Three years later, the Tupac Amaru Revolutionary Movement (TARM) was added. This made the President pawn the Armed Forces, in general, from December 1982 and the Marine Corps, in particular, in January 1983. This body was deployed in the Department of Ayacucho and, for 8 years, faced the subversions in the highlands and in the jungle of the provinces of Huanta and La Mar, characterized by high rates of violence. In addition, it was forced to act also in the Amazon region and in 1988 it took charge of the Naval Protection and Security System in Lima and Callao.

Later, in 1991, the entire Navy was involved in an armed conflict of a noninternational character. These Marine Corps carried out unconventional operations, such as the assault of the San Juan Bautista prison, better known as El Fronton, following a riot 
that broke out in June 1986, and the rescue of hostages from the Residence of the Japanese Ambassador in Lima in December 1996, taken by the TARM.

The 1990s also saw the marine infantry participating in United Nations peacekeeping missions, as was the case of Argentina in Cyprus and in Haiti (see Lafferriere and Soprano, 2016).

In order to ensure its capacity for power projection, the Brazilian Navy maintains the Fuzileiros Navais in permanent condition of preparation and employment. It should also be noted that marines are involved in internal law and order missions, providing logistical support for armored personnel carriers in Police Operations in the communities of the Maré Complex, a colony of the City of Rio de Janeiro (Notanf, 2014:3). The objective of this joint operation between the government of the state of Rio de Janeiro, the federal government and the Marine Corps themselves, is to create an atmosphere of peace and to combat organized crime. The operation in said Complex, named Operation San Francisco, lasted a year, two months and twenty-five days. The marines worked together with the Army, to achieve the pacification of an area that houses more than 140 thousand people (Notanf, 2015:7).

The Mexican Marine Corps participated intensely in the war against the organized crime at the time of president Felipe Calderón's administration:

During the first five years of President Calderón's term, the Marine Corps captured several important drug traffickers and contributed to the strengthening of the rule of law [...] according to Navy reports "During the first five years of President Calderón, the Navy of Mexico carried out 57,005 operations against drug trafficking. (Rivera Cabrieles, 2012: 428)

In contrast, the intensive use of the Marines in the Calderonist crusade against drug trafficking increased the number of citizen complaints for alleged human rights violations at the National Commission on Human Rights (CNDH), as well as of recommendations of the very own ombusman addressed to the Secretary of the Navy / Mexican Navy (SEMAR).

In addition, the Mexican Marine Corps performed operations of protection and surveillance of strategic facilities, such as those of Mexican Petroleum Company (PEMEX) and the Federal Electricity Commission (CFE), which are located on the maritime coast. It participated in international humanitarian aid missions in the neighboring region, transportating food to Haiti, providing logistical assistance in Belize when Arthur hit the country, and aiding Guatemala due to problems caused by the eruption of the Pacaya volcano (Ibid.: 436).

Taking stock of Latin America's Marine Corps, most of their doctrines share one aspect: the expansion of its missions and functions, given their orientation towards amphibious war, which allowed them to act as immediate intervention forces. This is explained by the very nature of the land component of the Navy, which is synthesized in its versatility and flexibility as distinctive notes.

It is important to insist on the added value of having Marine Corps, an elite force whose essential feature is the ability to adjust to the changing circumstances of the environment, to be able to respond to the mission given to them.

\section{4. ....and the future.}

In 1999, during a bilateral meeting held between the USMC General Commander, James Joles, and the Argentine Marine Corps Commander, Rear Admiral Oscar 
Monnereau, new ways to promote inter-American military cooperation were considered. The two Commanders agreed to organize a meeting of leaders of Hemispheric Marine Corps, where the Marine Leaders of the Americas Conference (MLAC) was created. The Ecuadorian Navy volunteered to organize the first conference and, since then, seven versions of these conferences have been held on different topics, the following being among them:

- Guayaquil - Ecuador 2001 - First Conference "Capacities and organizational structure of Hemispheric Marine Corps";

- Cartagena - Colombia 2004 - Second Conference "Role of Marine Corps in the fight against drug trafficking, terrorism and other transnational threats affecting the region";

- Santiago de Chile - Chile 2006 - Third Conference "Challenges in security and stability operations";

- Rio de Janeiro - Brazil 2009 - Forth Conference "Humanitarian \& Peacekeeping Operations";

- Lima - Peru 2011 -Fifth Conference "Participation of Regional Marine Corps in security operations";

- Cartagena - Colombia 2015 - Sixth Conference "The regional approach to Disaster Care and Humanitarian Assistance"; and

- Mexico City - Mexico 2018 - Seventh Conference "The role of the Marines in the maintenance of the Rule of Law".

The countries which attended these conferences are, in alphabetical order, Argentina, Belize, Bolivia, Brazil, Canada, Chile, Colombia, Dominican Republic, Ecuador, El Salvador, Guatemala, Honduras, Mexico, Nicaragua, Panama, Paraguay, Peru, United States of America and Uruguay.

It is worth noting that this type of space is reserved for the Marine Corps which, unlike the USMC, in Latin America depend on the Navy, that is, they lack autonomy. This is likely to be due to the new missions entrusted to them by the political power, in the light of the risks and threats to national security that are often beyond the capabilities of other coercive instruments of the State and which force the Marine Corps to comply with non-traditional missions in support of civilian authorities.

This is recognized by the International Red Cross Committee:

Maintaining law and order is the responsibility of civil authorities. It is the task of the civil police [...] The ordinary role of the armed forces of a State is to defend national territory against external threats (international armed conflict) and to deal with internal (non-international) armed conflict situations. However, armed forces may be required to come to the assistance of civil authorities to deal with much lower levels of violence that may be characterized as internal disturbances and tensions. (ICRC 2015: 6)

In many cases, this is a gray zone between war and peace, where humanitarian norms and human rights norms do not appear well assembled and whose victims often lack legal protection. And although the level of violence does not reach the threshold of an armed conflict, the persistence of violent acts can and does breach the public order of the State, the domestic law of each country and international human rights laws.

However, the Marines in Latin America are inserted in an operational environment marked by the following common denominators of the countries of the region: 
-Inequality, since the states of this subcontinent are those with the highest inequality rates in the world.

-Endemic violence, as Latin American countries are leading the murder rate per 100,000 inhabitants, which is the indicator proposed by the World Health Organization (WHO), and most of them surpass the rate of 10 murders per 100,000 inhabitants, which the WHO considers endemic violence.

- Corruption, with the exception of Chile, Uruguay and Costa Rica, all the states of the region have high rates of corruption, a scourge inextricably linked to impunity, meaning that most offenders are not penalized.

- Impunity, understood in its double meaning: on the one hand, it means that the majority of the delinquents and perpetrators are not penalized; and, on the other hand, that there is a small group of privileged "untouchables" linked to abysmal social differences, who will never be touched by the long arm of the law.

- General distrust, not only in the fundamental institutions of the republic and democracy, but also interpersonal distrust, that is, in the neighbor.

All of these significantly affect the social capital, understood as the values and institutions that allow a society to function in harmony, and explain the expansion of the missions and functions of the Armed Forces, in most Latin American countries, and their Marine Corps, in particular.

It is in this context that we find it necessary to pose questions about the dominant naval paradigms and the future projections.

\section{Brief Considerations on the Naval Paradigms of Latin America (more details in Moloeznik, 2016: 137-161, and see, Till, 2013: 116-118)}

From our perspective, there are three dominant naval models in the region: the Brazilian, the Chilean, and the Colombian models; and each of them can be correlated with the three types of navies identified by the British classic naval doctrine. (Ministry of Defence, 2017)

Brazilian navy (Marinha do Brasil)

It is the only naval power in Latin America to own an aircraft carrier. In its documented plans, it aspires to develop an ambitious process of modernization and expansion, to become a genuine blue water navy, capable of projecting its power on the high seas.

The Plans of Equipment and Articulation of the Brazilian Navy (PEAMB) for the next 30 years include the following projections:

-2 aircraft carrier of $40,000 \mathrm{TN}$;

-4 Landing Helicopter Dock (LHD) of 20,000 tons;

-30 Escort ships;

-15 Conventional oceanic submarines;

-5 Nuclear powered submarines; and

-62 oceanic patrol vessels.

To ensure the goal of denying the use of the sea, Brazil will have a large-scale submarine naval force, consisting of conventional and nuclear propulsion submarines with missiles. Among the high seas vessels, the Navy will give special attention to the design and manufacture of multi-purpose vessels which may also serve as aerodrome vessels. 
As for its Marine Corps, the aim is to have a body of expeditionary character for excellence in the future, in line with its aspirations to occupy an armchair as a permanent member of the UN Security Council.

Chilean navy (Armada de Chile)

The Chilean Navy can be classifed as a green water navy, with some projection of its naval power, without neglecting the preservation of its national sovereignty in the sea.

It centers on the frigates (oceanic combat units), considered both protective forces and forces of projection. Chilean naval strategy prioritizes the flexibility, versatility and combat power of these ships as they allow to cause unbalancing effects, which is why they acquire strategic connotation.

Regarding its marines, they will continue with the pattern of elite strength, versatility and lightness, under the idea-force of quality.

Colombian navy (Armada Nacional)

It is a Navy inadequately equipped to deal with responsibilities as a bi-oceanic force. Its fleet modernization efforts will focus on patrol vessels and patrol aviation. In particular, since 2000, it has increased its role in the counter-insurgency campaign and in combating drug trafficking and related crimes, especially through its Marine Corps and naval aviation. This explains the exponential growth of the Colombian Marine Corps in the last decade, by giving emphasis on quantity.

Since the "narco-terrorist" threat is the greatest operational challenge for the national Navy, it can be categorized as brown water navy, with weaknesses and at the same time asymmetry, which will force it to innovate, reorient and rethink the operational and strategic concept permanently.

3.2. Future projections

In the case of the Marine Corps, there is a debate between two tendencies: "dwarfism" ("enanismo" in Spanish) - light forces, with high level of preparation and versatility - and "gigantism" ("gigantismo" in Spanish) - heavy forces, conceived as of expeditionary character. In both patterns, emphasis is placed on non-material or intangible qualitative factors, by recognizing marines as elite forces.

For a well-known British writer, the current emphasis on maneuvering the ship to the target means that modern and well-equipped Marine Corps can have a very considerable scope [...] Today, the idea is to bring the Marines as quickly and as direct as possible to the target. For this reason, US Marines have been re-designated as "expeditionary" rather than "amphibious," although, it is likely that "reaching the shore" will continue to be one of their main achievements. Given its previous veneration for famous battles like Iwo Jima and Okinawa, this is a major paradigm shift. (Till, 2013: 280 ss)

\section{According to Brazilian Marine Corps}

The modern concept of amphibious operation is characterized by power projection from the sea to shore, no matter the hostility level of the environment and also the type of mission to be accomplished. It is also linked to the concept of maneuver warfare and embraces, including but not limited to, landings that aim to evacuate non combatants, to supply humanitarian assistance, or to protect threatened populations and victims of natural disasters. To perform such a wide range of tasks and to fulfill different types of 
employment, the Marines adopted a flexible organizational model called Marine AirGround Task Force (MAGTF). (Medeiros, 2013: 136)

A British expert emphasizes aspects such as transportability by sea, speed, maneuver and, increasingly, operations based on small fractions, in which marine forces tend to be self-contained, with delegation of command and with "light" terms in the area of armor and firepower; which explains the development of a new type of multi-purpose amphibious warship that will provide full and specialized support to the high-level amphibious group (Till, 2013: 328-329).

The Marine Corps stands in a fundamental part of the Naval Power of every sovereign nation, which in turn, is key to guarantee the integrity, stability and permanence of the State. This explains the intensive use of the Marines in most countries of the region, in order to deal with the growing threat of organized crime and to support civil authorities, thereby distorting their amphibious vocation and traditional missions.

However, in Latin America there is an increase in the relative importance of the Marine Corps, as an ad hoc instrument to guarantee the fulfillment of non-conventional operations such as imposing law and order, which has probably led to the consolidation of the Marine Leaders of the Americas Conference (MLAC).

This is reflected in the central theme developed in the successive versions of the MLAC, namely:

- the role of the Marine Corps and the Navy in the fight against drug trafficking, terrorism and other transnational threats that affect the region, that is, the so-called emerging threats, which impose the debate on unconventional missions to the armed forces, in general, and the Marine Corps, in particular.

- the challenges in security and stability operations, as well as disaster relief and humanitarian assistance, humanitarian operations and peace operations; missions of a subsidiary nature, but no less important than the traditional ones, as a contribution to international peace and security under the mandate of the Security Council of the United Nations Organization, and within the framework of national systems of defense or civil protection, when not in solidarity with sister countries victims of natural or socioorganizational catastrophes.

- the participation of the Marine Corps of the region in internal security operations, which means the militarization process of public security in Latin America, with the exceptions of Argentina, Uruguay and Chile (the South Cone); in other words, the commitment of the Marine Corps in missions and functions of a police or para-police nature, when the capacities of the police are insufficient.

- the large number of Latin American states which forsee the role of the Marines Corps in the maintenance of the rule of law, which lies in a traditional mission of the armed forces, because it is a matter of national security, linked to the basic institutions of the State, to the preservation of constitutional order, human rights and democracy.

\section{Conclusions}

The variety of missions that the Marine Corps have could lead to the dispersion of efforts and the distortion of mandates contemplated in international and national legal instruments recognized by Latin American countries. Therefore, Till (2013: $120 \mathrm{ss}$ ) recommends that: "[...] It is better to master some functions than to be mediocre in many. 
[...] Developing a "specialty niche" in which high standards are sought in one area tends to compensate for the national irrelevance in others."

In the case of the Marine Corps of Latin America, MLAC maintains correspondence with this strength, by providing a forum that contributes to the sharing and exchanging of experiences and good practices, contributing to the solution of common problems.

The lessons learned in democratic countries demonstrate that intelligence services, exchange of information and international cooperation are key to face the socalled "new threats" to the national security. The Marine Corps are only a coercive instrument of the State and their success will depend on the intelligence gathered and shared.

However, even in exceptional situations that require the intervention of the armed forces, like the Marines, the International Committee of the Red Cross recommends the formal declaration of state of exception/emergency: (ICRC 2015: 22)

The emergency must be officially proclaimed by the domestic body empowered to do so. This enables the population to know the exact material, territorial and temporal scope of the emergency measures and also prevents de facto derogations and retroactive attempts to justify human rights violations.

In conclusion, Latin America Marine Corps -between the past and the future- find their roots in the rich Portuguese and Spanish traditions, which are part of the historical evolution of the Ibero-American republics. The Corps were only later in the navy as one of its components and they have recently acquired relative autonomy in the hand of emerging threats, on account of their own nature as a versatile, flexible, logistically simple instruments with a high level of enlistment and which is relatively economical.

\section{Bibliography}

-ABC Journal, Madrid, 28/02/2012, "Las diez mayores gestas de la Infantería de Marina. El Príncipe Felipe participa en la celebración del 475을 Aniversario de este Cuerpo de élite de la Armada Española". Available in:

http://www.abc.es/20120228/espana/abci-mayores-gestas-infanteriamarina-201202271311.html <Consulted for the last time on February 27, 2018>

-Argentinean Navy / Armada Argentina (2018), Poder Naval - Infantería de Marina Historia. Available in: http://www.ara.mil.ar/pag.asp?idltem $=248<$ Consulted for the last time on March 2, 2018>

-Bielinski, Alba Carneiro (2008). Os fuzileiros Navais na História do Brasil. Rio de Janeiro: Agencia A2 de Comunicação. Available in: https://es.scribd.com/doc/52035222/Livro-Os-Fuzileiros-Navais-Na-HistoriaDo-Brasil <Consulted for the last time on October 13, 2018>

-Blakeway, Denys (1992), The Falklands War, London, Sidgwick \& Jackson, in Association with Channel FourTelevision Company Limited.

-Brazilian Navy / Marinha do Brasil (2018a). Available in: https://www.marinha.mil.br/cgcfn/?q=unifil

<Consulted for the last time on February 27, 2018> 
-Brazilian Navy / Marinha do Brasil (2018b), Corpo de Fuzileiros Navais - Histórico. Available in: https://www.marinha.mil.br/cgcfn/?q=historico <Consulted for the last time on February 27, 2018>

-Cabanellas de Torres, Guillermo (Director) (1983), Diccionario Militar (Aeronáutico, Naval y Terrestre), Buenos Aires, Editorial Claridad S.A., v. IV H-N.

-Chilean Navy / Armada de Chile (2018a). Available in:

http://www.armada.cl/armada/armada-actual/escuela-de-infanteria-demarina-del-comandante-jaime-charles/2014-05-07/113932.html <Consulted for the last time on February 27, 2018>

-Chilean Navy / Armada de Chile (2018b) Bernardo O'Higgins y el Mar de Chile. Available in: http://www.armada.cl/armada/tradicion-e-historia/archivos-historicos/bernardo-o-higginsy-el-mar-de-chile/2014-05-16/153406.html <Consulted for the last time on February 27, 2018>

-Colombian National Navy / Armada Nacional, República de Colombia (2018), “18 Comandantes de Infantería de Marina de las Américas se reúnen en Cartagena". Available in: https://www.armada.mil.co/es/content/18-comandantes-deinfanteria-de-marina-de-las-americas-se-reunen-en-cartagena $<$ Consulted for the last time on February 27, 2018>

-Foster, Simon (1998), Hit the Beach (The drama of Amphibious Warfare), London, Cassell Military Classics.

-Hastings, Max y Jenkins, Simon (1983), The Battle for the Falklands, London, Book club Associates/Michael Joseph.

-Hoffman, Jon T. (Colonel USMCR) (2002), USMC: A complete history, Washington, D.C., Marine Corps Association.

-Informe Rattenbach (1988), El drama de Malvinas, Buenos Aires, Ediciones Espartaco. -Informador Público (2015), "Recuerdo de un valiente: El Almirante IM Carlos Busser." Available in: https://www.informadorpublico.com/historia/recuerdo-de-unvaliente-el-almirante-im-carlos-busser

$<$ Consulted for the last time on June 3, 2018>

-International Committee of the Red Cross (ICRC) (2015), Violence and the Use of Force. Geneva. Available in: https://www.icrc.org/en/publication/0943-violenceand-use-force <Consulted for the last time on October 13, 2018>

-Lafferriere, Horacio G. y Soprano, Flavio G. (2016), “Participación militar argentina en misiones de paz. Desafíos para la política de Defensa e influencia en la organización y funcionamiento en las Fuerzas Armadas 1990-2013". Relaciones Internacionales, № 50/2016, pp. 273-297. Available in: http://dx.doi.org/ $<$ Consulted for the last time on February 27, 2018>

-Liddell Hart, Basil H., Sir (1960), "Marines and Strategy", Marine Corps Gazette, The Professional Journal of U.S. Marines, Quantico, VA., July.

-Luttwak, Edward and Koehl, Stuart. L. (1991), The Dictionary of Modern War (A guide to 
the ideas, institutions and weapons of the modern military power vocabulary), New York, Gramercy Books.

-Medeiros, Anderson da Costa (2013), Fuzileiros Navais: confie neles, Rio de Janeiro, Eunagellus Comunicacao.

-Mexican Navy / Secretaria de Marina de México / Armada de México (2017). Available in: http://www.gob.mx/semar <Consulted for the last time on June 5, 2017>

-Ministry of Defence (2017), Joint Doctrine Publication 0-10, UK Maritime Power, 5th Edition available in:

https://assets.publishing.service.gov.uk/government/uploads/system/uploads/attachment _data/file/662000/doctrine_uk_maritime_power_jdp_0_10.pdf <Consulted for the last time on October 14th, 2018>

-Moloeznik, Marcos Pablo (2011), "Radiografía del poder naval mexicano (la armada de México frente a sus pares de América Latina)". Revista del CESLA - Universidad de Varsovia, pp. 39-71.

-Moloeznik, Marcos Pablo (2016), Capítulo V, “Derrotero y paradigmas navales en Latinoamérica"; en, Katarzyna Krzywicka y Paweł Trefler, Transformaciones geopolíticas y nuevas amenazas en América Latina, Lublin, Uniwersytetu Mariicurie - Skłodowskiej, v. IV de la Colección Estudios iberoamericanos de la UMCS, pp. 137-161.

-Notanf (2014), “Noticias e eventos do Corpo de Fuzileiros Navais”, Janeiro/Fevereiro/Março.

-Notanf (2015), Noticias e eventos do Corpo de Fuzileiros Navais, Julho/Agosto/Setembro.

-Ortiz Sotelo, Jorge (2000), Acción y Valor (Historia de la Infantería de Marina del Perú), Lima, Forza Seguridad Corporativa / Asociación de Oficiales de Infantería de Marina del Perú / Securitas.

-Portuguese Marine Corps / Corpo de Fuzileiros (2017). Available in: http://www.globalsecurity.org/military/world/europe/pt-fuzileiros.htm $<$ Consulted for the last time on June 2, 2018>

-Portuguese Navy / Marinha Portuguesa (2018), Fuzileiros Navais. Available in: http://tropasearmas3.xpg.uol.com.br/portugal-fuzileiros-navais.htm <Consulted for the last time on February 27, 2018>

-Rivera Cabrieles, Leticia (2012), Historia General de la Infantería de Marina Mexicana, México, Secrertaría de Marina/Armada de México, t. II, Capítulo 7 Desafíos y perspectivas de la infantería de marina contemporánea (1994-2012). Available in:

http://www.semar.gob.mx/unhicun/publicaciones_historicas/serie_unhicun /historia_infanteria/historia_infanteria5_t2.pdf < Consulted for the last time on August 11, 2018>

-Robacio, Carlos H. y Jorge Hernández, Jorge (1996), Desde el frente. Batallón de Infantería de Marina No. 5, Instituto de Publicaciones Navales, Buenos Aires.

-Rodríguez Ávila, M. E. (2012). “La infantería de Marina en el siglo XIX, 1821-1867”, en: 
Rivera Cabrieles, Leticia, Historia General de la Infantería de Marina Mexicana, México, Secretaría de Marina. Secretaría de Marina/ Armada de México, t. I.

-Royal Marines (2014), History. Available in:: <http://www.royalnavy.mod.uk/news-andlatest-activity/features/rm350 $><$ Consulted for the last time on April 30, 2016>

-Royal Spanish Navy / Real Armada Española (2012a), Comandancia General de Infantería de Marina, Infantería de Marina 475 aniversario 1537-2012. Available in: http://www.ieee.es/Galerias/fichero/OtrasPublicaciones/Nacional/LIBRO_C ONMEMORATIVO_475_ANIVERSARIO_IXMx_.pdf < Consulted for the last time on February 27, 2018>

-Royal Spanish Navy / Real Armada Española (2012b), Reseña histórica. Available in: http://www.armada.mde.es/ArmadaPortal/page/Portal/Armadaespannola/c onocenos_organizacion/prefLang_es/03_Flota--04_Flota-Fuerza-InfanteriaMarina--02_historia_FIM_es <Consulted for the last time on February 27, 2018>

-Scheina, Robert L. (1987), Latin America: A Naval History, 1810-1987, Annapolis, MD, Naval Institute Press.

-Slater, Jock Sir (Admiral) (1998), "The Maritime Contribution to Joint Operations"; in, Journal of the Royal United Services Institute (RUSI), vol. 143, pp. 20-24, december 1998. Available in: http://dx.doi.org/10.1080/03071849808446322 $<$ Consulted for the last time on June 5 2018>

-Spanish Marine Corps / Infantería de Marina Española / (2018). Historia de la Infantería de Marina. Available in: http://www.revistanaval.com/wwwalojados/infanteriademarina/historia.htm $<$ Consulted for the last time on February 27, 2018>

-Sohr, Raúl (1990), Para entender la guerra, México, Consejo Nacional para la Cultura y las Artes / Alianza Editorial Mexicana.

-Thompson, Julian (1985), No Picnic: 3 Commando Brigade In The South Atlantic, London, Leo Cooper Ltd / Secker \& Warburg Ltd .

-Till, Geoffrey (2013), Seapower: A Guide for the Twenty-First Century (Cass Series: Naval Policy and History), New York, 3rd Edition, Routledge Publisher.

-United States Marine Corps (USMC) (1995), Leading Marines, FMFM 1-0, Washington, D.C., Department of the Navy, Headquarters United States Marine Corps. 